\section{Research Article: Inter-relationship analysis of yield and yield component traits in little millet (Panicum sumatrense) genotypes}

\author{
口. MANIMOZHI SELVI AND A. NIRMALAKUMARI
}

Article Chronicle: Received : 14.07.2017;

Accepted : 29.07.2017

\section{KeY Words:}

Little millet, Yield component traits, Correlation, Path coefficient analysis, Inter relationship analysis

Author for correspondence :

\section{MANIMOZHI}

SELVI

Centre for Plant

Breeding and Genetics,

Tamil Nadu Agricultural

University, COIMBATORE

(T.N.) INDIA

Email: manimozhiagri

2005@gmail.com

See end of the article for

authors' affiliations
SUMMARY : The study was conducted to determine the correlation and path co-efficients among the 30 little millet genotypes, comprised of 26 germplasm accessions and four check varieties viz., $\mathrm{CO}_{2}, \mathrm{CO}$ 3, CO (Samai) 4 and OLM 203. The experiment was laid out in a Randomized Complete Block Design (RCBD) with three replications during summer, 2013 (Jan - May) at Millets Breeding Station, Tamil Nadu Agricultural University, Coimbatore. Both at genotypic and phenotypic levels single plant grain yield showed positive and significant correlation with plant height (0.696 and 0.694), panicle length ( 0.678 and 0.599$)$, days to 50 per cent flowering $(0.608$ and 0.530$)$, peduncle length $(0.556$ and 0.429$)$, flag leaf length (0.549 and 0.515$)$ and thousand grain weight (0.448 and 0.441$)$, respectively. Flag leaf width (-0.424 and -0.405) exhibited significant but negative genotypic and phenotypic correlation co-efficients with single plant grain yield. Path co-efficient analysis revealed that among the 11 yield component traits studied, panicle length (1.661), flag leaf width (0.941), culm branches per plant (0.812), plant height $(0.678)$, thousand grain weight $(0.564)$, days to 50 per cent flowering $(0.470)$, panicle exertion $(0.452)$ and peduncle length $(0.350)$ exerted high positive direct effect on single plant grain yield while, basal tillers per plant (-1.635), flag leaf length (-0.910) and single plant dry fodder yield (-0.716) showed high negative direct effect on single plant grain yield. From the above results of path co-efficient analysis, it might be concluded that improvement in single plant grain yield could be brought about by selection for late flowering, tall plant stature, long peduncle, lengthy panicle and bolded size seeds in the material studied.

How to cite this article : Selvi, V. Manimozhi and Nirmalakumari, A. (2017). Inter-relationship analysis of yield and yield component traits in little millet (Panicum sumatrense) genotypes. Agric. Update, 12 (TECHSEAR-4): 1126-1129; DOI: 10.15740/HAS/AU/12.TECHSEAR (4)2017/1126-1129. 